Introduction

Acyclovir is widely used to treat children with Herpes Simplex Virus (HSV) and Varicella Zoster Virus (VZV) infections. For HSV/VZV meningoencephalitis, the U.S. Food and Drug Administration recommends intravenous (IV) acyclovir $20 \mathrm{mg} / \mathrm{kg} /$ dose (high-dose) 8 hourly for children $\geq 3$ months old whereas American Academy of Paediatrics recommends $15 \mathrm{mg} / \mathrm{kg} / \mathrm{dose}$ 8 hourly for children 3 months to 12 years old due to reports of nephrotoxicity, especially in those $\geq 12$ years old with concomitant ceftriaxone.

\section{Aim of Study}

To determine the incidence of acute kidney injury (AKI) in those receiving high-dose IV acyclovir for meningoencephalitis in KK Women's and Children's Hospital, Singapore (KKH)

Methodology

A retrospective cohort study of all paediatric patients admitted to KKH from 1st March 2016 to 31st March 2017 (CIRB 2017/2507)

\begin{tabular}{|c|c|}
\hline $\begin{array}{l}\text { Inclusion } \\
\quad \& \\
\text { Exclusion } \\
\text { Criteria }\end{array}$ & $\begin{array}{l}\text { - Included patients aged } 0 \text { to } 18 \text { years old and } \\
\text { received at least one dose of high dose IV } \\
\text { acyclovir for treatment of meningoencephalitis } \\
\text { - Excluded if patient had pre-existing chronic } \\
\text { kidney disease or received IV or oral acyclovir } \\
\text { for HSV prophylaxis }\end{array}$ \\
\hline $\begin{array}{l}\text { Data } \\
\text { collection }\end{array}$ & $\begin{array}{l}\text { - Patient demographics } \\
\text { - Clinical data }\end{array}$ \\
\hline $\begin{array}{c}\text { AKI } \\
\text { staging }\end{array}$ & $\begin{array}{l}\text { - Estimated Glomerular Filtration Rate (eGFR) } \\
\text { determined using the Schwartz equation } \\
\text { - Patients developing renal impairment more } \\
\text { than } 1 \text { week after the end of treatment were } \\
\text { excluded (Table 1) }\end{array}$ \\
\hline $\begin{array}{l}\text { Statistical } \\
\text { analyses }\end{array}$ & $\begin{array}{l}\text { - Descriptive statistics } \\
\text { - Data analysis was done using REDCap and } \\
\text { Microsoft Office Excel } 2010\end{array}$ \\
\hline
\end{tabular}

\section{Results and Discussion}

Of 214 children on IV acyclovir, 45 had other indications and 30 received low-dose acyclovir for meningoencephalitis; hence, 139 children were included (mean age: 5.28 \pm 4.8 years).

- Seventy six percent of the children were aged 3 months to 12 years old and $51.8 \%$ were Chinese.

- The median duration of IV acyclovir was 2 days [interquartile range:2-3 days] and all patients were adequately hydrated.

Table 1. Incidence of AKI according to pRIFLE and KDIGO criteria

\begin{tabular}{|c|c|c|}
\hline \multirow{2}{*}{ pRIFLE criteria; n (\%) } & Definition & $N=139$ \\
\hline & \multirow{7}{*}{$\begin{array}{l}\text { eGFR decrease }<25 \% \\
\text { eGFR decrease } \geq 25 \% \\
\text { eGFR decrease } \geq 50 \% \\
\text { eGFR decrease } \geq 75 \% \text { or } \\
\text { eGFR }<35 \mathrm{~mL} / \mathrm{min} / 1.73 \mathrm{~m}^{2} \\
\text { Persistent failure }>4 \text { weeks } \\
\text { Persistent failure }>3 \text { months }\end{array}$} & \multirow{5}{*}{$\begin{array}{c}137(98.6) \\
0(0.0) \\
1(0.7) \\
1(0.7)\end{array}$} \\
\hline No renal injurya & & \\
\hline Renal risk & & \\
\hline Renal injury & & \\
\hline Renal failure & & \\
\hline Renal loss & & $0(0.0)$ \\
\hline End-stage & & $0(0.0)$ \\
\hline KDIGO criteria; n (\%) & & \\
\hline Stage 1 & $\begin{array}{l}\text { Increase } 1.5-1.9 \times \text { baseline } \\
\text { or increase of } \geq 26.5 \mu \mathrm{mol} / \mathrm{L}\end{array}$ & $1(0.7)$ \\
\hline Stage 2 & Increase $2-2.9 x$ baseline & $0(0.0)$ \\
\hline Stage 3 & $\begin{array}{l}\text { Increase }>3 x \text { baseline or } \\
\text { Initiation of renal replacement } \\
\text { therapy or eGFR }<35 \mathrm{~mL} / \mathrm{min} / \\
1.73 \mathrm{~m} 2(<18 \mathrm{v})\end{array}$ & $1(0.7)$ \\
\hline
\end{tabular}

repeated serum creatinine measurement

- Two children (1.4\%) aged 12 and 15 years old developed AKI $>$ Occurred after an average of 3.5 days from acyclovir initiation $>$ Both did not receive any concurrent nephrotoxic drugs but were co-treated with IV ceftriaxone

$>$ Both were managed supportively with hydration in the general ward and their serum creatinine normalised
- Lower percentage of AKI (1.4\%) than the $13.1 \%$ occurrence reported with high-dose acyclovir by Rao et. Al,

- Likely because our patients were well-hydrated and patients with chronic kidney disease were excluded

> Reduces risk of intra-tubular crystallization of acyclovir in kidneys

- Microbial resolution based on cerebrospinal fluid (CSF) or blood HSV/VZV polymerase chain reaction (PCR) could not be determined to assess the efficacy of high dose IV acyclovir

- One hundred and thirty three children (95.7\%) improved clinically and were discharge well and stable.

\begin{tabular}{|c|c|}
\hline Non-renal adverse events & $N=139(\%)$ \\
\hline Leukopenia & $6(4.3)$ \\
\hline Neutropenia & $4(2.9)$ \\
\hline Thrombocytopenia & $6(4.3)$ \\
\hline Elevated liver enzymes & $9(6.5)$ \\
\hline Rash & 0 \\
\hline Phlebitis & 0 \\
\hline
\end{tabular}

- Most did not develop any adverse events

- Some of the non-renal adverse events may be complications of their viral infections, instead of being entirely attributed to IV acyclovir.

Conclusion

- In our study, incidence of AKI secondary to high-dose IV acyclovir for paediatric meningoencephalitis was $1.4 \%$, lowe than $13.1 \%$ reported in two studies, where the median onset of AKI was 1-14 days.

- Based on our study findings, considering the possibility of increased risk of treatment failure for dosing $<20 \mathrm{mg} / \mathrm{kg} / \mathrm{dose}$, high-dose IV acyclovir could be considered for treatment of HSV/VZV meningoencephalitis in $\leq 12$ years old. However, hydration and close monitoring of renal function would be prudent when high-dose IV acyclovir is used. 